\title{
Cytological changes in oral mucosa induced by smokeless tobacco
}

\author{
Mohammed E. A. Mohammed ${ }^{1}$, Eid I. Brima ${ }^{1,2}$
}

\begin{abstract}
INTRODUCTION This study investigated the cellular changes in the mouth of smokeless tobacco (shamma) users among Saudi citizens from the Najran region. METHODS Healthy 61 shamma users and healthy 61 non-users participated in this study after informed consent. A mouth swap was taken from each study subject and investigated for cellular changes using a Papanicolaou stain. The results were analyzed using the t-test per cent of the StatPac statistical program. RESULTS Keratinization, binucleation and combined results were associated with shamma use. The number of shamma users with abnormal histology was $14(22.9 \%)(\mathrm{p} \leq 0.0001)$. The shamma types associated with the abnormal cytology were: Suhaily $(9 / 36 ; p=0.0014)$, black $(2 / 9 ; p=0.08)$, white $(2 / 6$; $\mathrm{p}=0.41)$, and red $(1 / 1 ; \mathrm{p}=1.00)$. The percentage of the tissues with abnormal histology decreased with the increase in the duration and frequency of smokeless tobacco use, except for the white shamma which increased with the increase in the frequency.

CONCLUSIONS Shamma use affected the mouth epithelial cytology of $22.9 \%$ of its users. The histological changes were inflammation, keratinization, binucleation, and atypia. The Suhaily smokeless tobacco was associated with the highest percentage of the abnormal cytology results, while the duration and frequency of smokeless tobacco use decreased the number of tissues with abnormal histology.
\end{abstract}

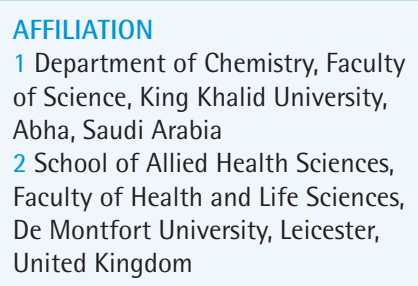

\section{KEYWORDS}

local Saudi snuff, cytological changes, keratinization, binucleation, dual abnormalities

Received: 4 December 2018 Revised: 22 March 2019 Accepted: 21 May 2019

\section{INTRODUCTION}

Smokeless tobacco is well known to be associated with mouth diseases, including leukoplakia, erythroplakia, and oral submucous fibrosis ${ }^{1}$. Leukoplakia, erythroplakia and oral submucous fibrosis are associated with cellular changes such as keratinization, enlarged nucleus, atypia, multi-nucleation, and inflammatory reaction ${ }^{2-6}$. All of the above smokeless tobacco-induced changes are considered as characteristics of carcinogenesis and metastasis ${ }^{7,8}$.

Smokeless tobacco in Saudi Arabia is known as shamma, prepared as a mixture of powdered unburned leaves from Nicotiana tabacum alone or mixed with leaves from Nicotiana rustica, Nicotiana glauca, carbonate of lime, ash, black pepper, oils, and flavorings. There are many types of shamma according to color (black, white, red, grey, brown, green, yellow) and origin: Suhaily, Afzal (Indian origin), Maswar (Afghanistan), and Toombak (Sudan) ${ }^{9}$.

Smokeless tobacco, including shamma, contains at least 30 chemicals that are associated with high cancer risk, including Tobacco-Specific Nitrosamines (TSNA), while the correlation between heart disease and blood pressure with smokeless tobacco is well known $^{10,11}$.

Changes in oral cellular appearance under the microscope are mostly due to malignancy, infection, infarction or necrosis, chemotherapy, and radiotherapy ${ }^{12}$. Atypical cellular changes can be seen in the cases of infarction, necrosis, and haemorrhage ${ }^{13}$. Hence, the aim of this study was to investigate the effect of shamma on the appearance of oral mucosa cells. 


\section{METHODS}

Sixty-one shamma users and 61 non-users among Saudi citizens from the Najran region were involved in this study. The cellular effects were studied of eight shamma types: Suhaily, Afzal, white, black, brown, grey, red, and yellow. All the study subjects were males of age 18-80 years for shamma users and 19-88 years for non-users. The age range was divided into three groups: 18-44, $45-64$ and $\geq 65$ years. The duration of shamma use was divided to two groups: $1-5$ and $6-10$ years; and the frequency (times/day) of use was categorized into three groups: $1-5,6-10$, and 11-15. This study was conducted after approval from the ethical committee of King Khalid University. The study subjects were involved after signing an informed consent.

Cytological smears from oral mucosa were collected from the study participants. The study subjects were told to wash their mouth with normal saline solution before the sampling process. The dipping site was dried with a smooth wipe to expel excess saliva. A smooth brush was used to scratch the site of snuffing and the tongue two times to ensure the collection of the samples from the inner layers of the oral mucosa. Each collected sample was smeared on a slide and fixed in $96 \%$ ethanol for 30 minutes. The fixed buccal smears were stained with the Papanicolaou stain ${ }^{14}$. The Papanicolaou stained slides were investigated using the $40 \times$ magnification of an Olympus light microscope. The cells were considered as atypia if they had: an irregular shape; hyperchromatism; irregular nuclear shape, size or border; and irregular cytoplasm size. Presence of two nuclei in the buccal cells was considered as binucleation, while accumulation of white blood cells was the marker of inflammation, and keratinization was confirmed by the yellow staining of keratins, the intermediate filament proteins.

Statistical analysis was done using the StatPac program for basic and advanced statistics. Comparison between the control and the cases was performed by the t-test per cent. The significance level was set at 0.05 .

\section{RESULTS}

The cellular changes induced by eight shamma types were studied. The eight shamma types and their use frequencies in the study population were: Suhaily (36), black (9), white (6), grey (4), yellow (3), red (1), afzal (1), and brown (1).

The interpretation of the Papanicolaou staining results showed the presence of eleven results with different percentages: normal, inflammatory cells, bacterial infection, atypia, keratinization, binucleation; and five combinations: atypia and inflammatory cells, keratinization and inflammatory cells, bacterial infection and inflammatory cells, binucleation and keratinization, and binucleation and inflammatory cells (Table 1 and Figures 1 and 2). Four results were seen in the oral histological samples of the shamma users and non-users: normal cells, inflammatory cells, atypia, and bacterial infection (Figure 1). The absolute numbers and percentages of each result are presented in Table 1. However, the percentages of the tissues with normal histology in the shamma users and non-users were $50.8 \%$ and $68.9 \%$, respectively $(\mathrm{p}=0.043)$ (Table 1). The percentages of the abnormal results in the shamma users and non-users were $49.2 \%$ and $31.1 \%$, respectively $(\mathrm{p}<0.001)$. The other seven results were associated with the use of shamma (not seen in the histology samples of the non-users) (Figure 2). Four shamma types induced the seven results: Suhaily, black, white and red (Table 2). Of the shamma associated abnormal cytology results, 64.3\% were due to the Suhaily type $(9 / 14 ; \mathrm{p}=0.28)$, while $25 \%(9 / 36 ; p=0.0014)$ of the Suhaily shamma were associated with the cellular changes (Table 2).

\section{Table 1. The Papanicolaou staining results of the} shamma user and non-user study subjects ( $\mathrm{N}=122)$

\begin{tabular}{|c|c|c|c|c|}
\hline & \multirow[t]{2}{*}{$\begin{array}{l}\text { Papanicolaou staining } \\
\text { result }\end{array}$} & $\begin{array}{c}\text { Shamma } \\
\text { user }\end{array}$ & $\begin{array}{l}\text { Shamma } \\
\text { non user }\end{array}$ & \multirow{2}{*}{$\begin{array}{c}p \\
(t-\text { test } \\
\text { per } \\
\text { cent })\end{array}$} \\
\hline & & n $(\%)$ & n $(\%)$ & \\
\hline 1 & Normala $^{\mathrm{a}}$ & $31(50.8)$ & $42(68.9)$ & 0.043 \\
\hline 2 & Inflammatory cell ${ }^{\mathrm{a}}$ & $14(23)$ & $15(24.6)$ & 0.84 \\
\hline 3 & Bacterial infection $^{a}$ & $1(1.6)$ & $3(4.9)$ & 0.31 \\
\hline 4 & Atypia $^{a}$ & $1(1.6)$ & $1(1.6)$ & 1.00 \\
\hline 5 & Keratinization ${ }^{b}$ & $3(4.9)$ & 0 & - \\
\hline 6 & Binucleated $^{b}$ & $2(3.3)$ & 0 & - \\
\hline 7 & Atypia + inflammatory cells ${ }^{b}$ & $2(3.3)$ & 0 & - \\
\hline 8 & $\begin{array}{l}\text { Keratinization + } \\
\text { inflammatory cells }{ }^{b}\end{array}$ & $3(4.9)$ & 0 & - \\
\hline 9 & $\begin{array}{l}\text { Inflammatory cells + } \\
\text { bacterial infection }\end{array}$ & $2(3.3)$ & 0 & - \\
\hline 10 & $\begin{array}{l}\text { Binucleation + } \\
\text { keratinization }^{b}\end{array}$ & $1(1.6)$ & 0 & - \\
\hline 11 & $\begin{array}{l}\text { Binucleation + } \\
\text { inflammation }^{\text {b }}\end{array}$ & $1(1.6)$ & 0 & - \\
\hline Total & & $61(100)$ & $61(100)$ & - \\
\hline
\end{tabular}

a Staining results seen in the shamma users and non-users. b Staining results associated with shamma use. 
Figure 1. Representative non-shamma associated Papanicolaou staining results

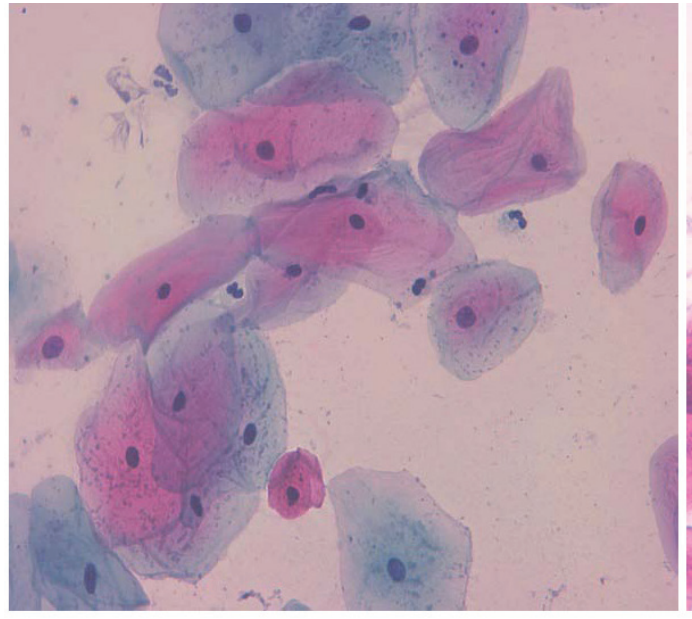

Inflammatory cells

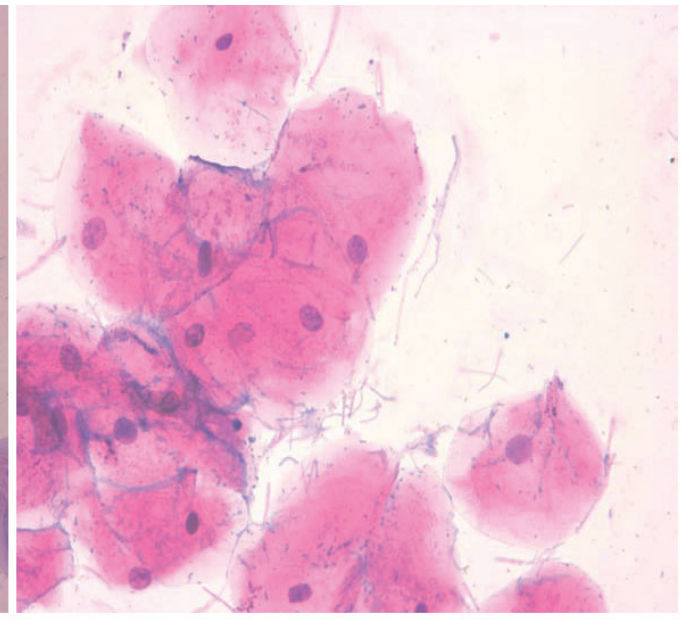

Bacterial infection

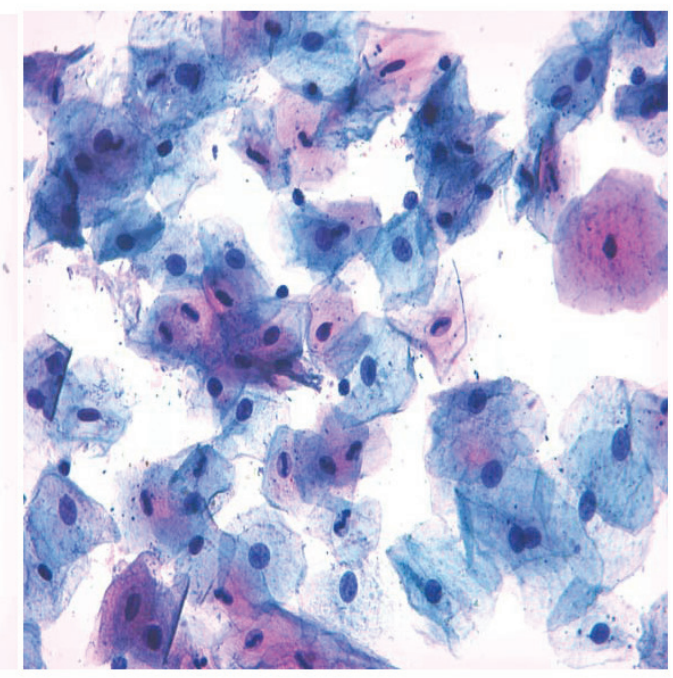

Atypia

Normal

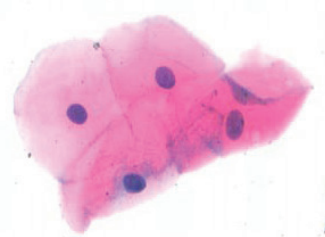

Figure 2. The oral mucosa cytological changes associated with Saudi smokeless tobacco

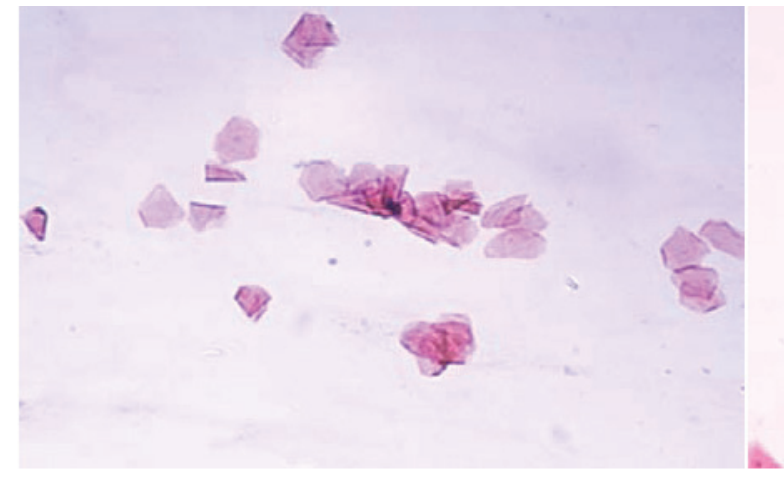

Keratinization

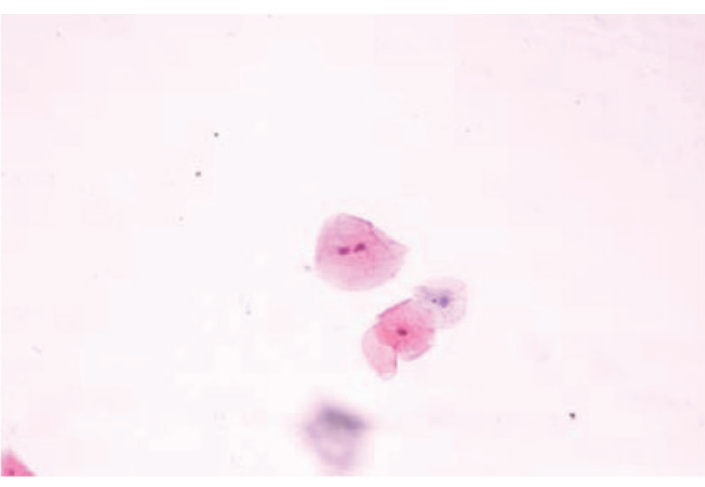

Binucleated cells 
Figure 2. Continued

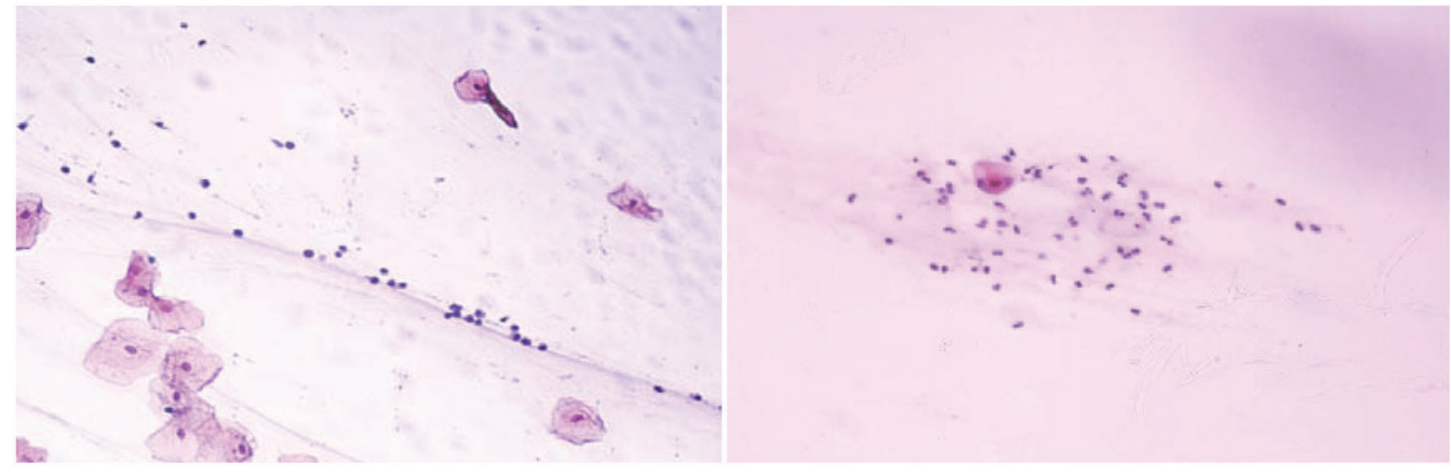

Keratinization and inflammatory cells

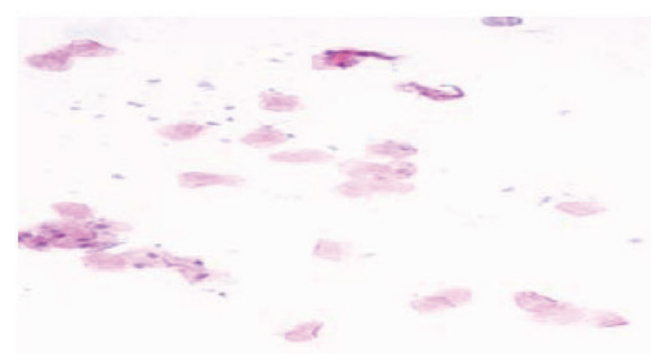

Binucleated and inflammatory cells

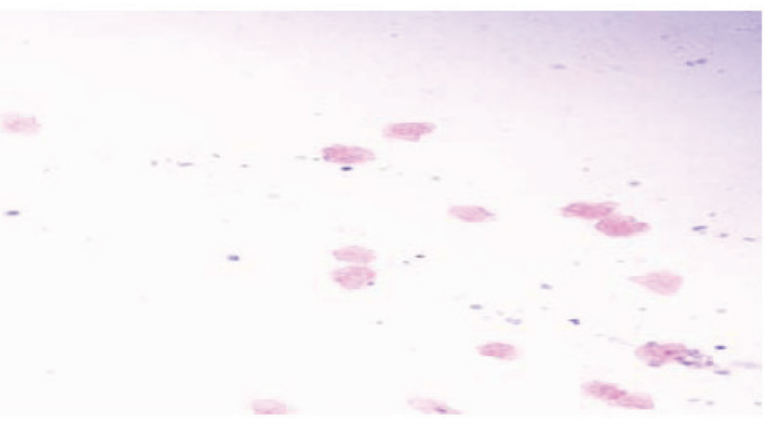

Keratinization and binucleated cells

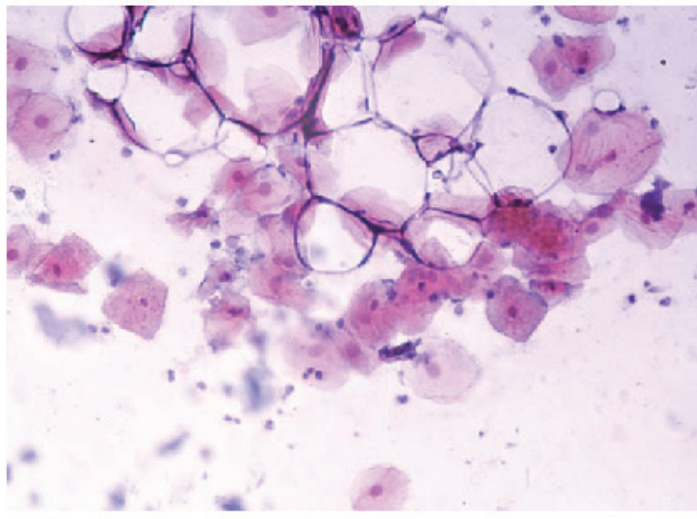

Inflammatory cells and bacterial infection

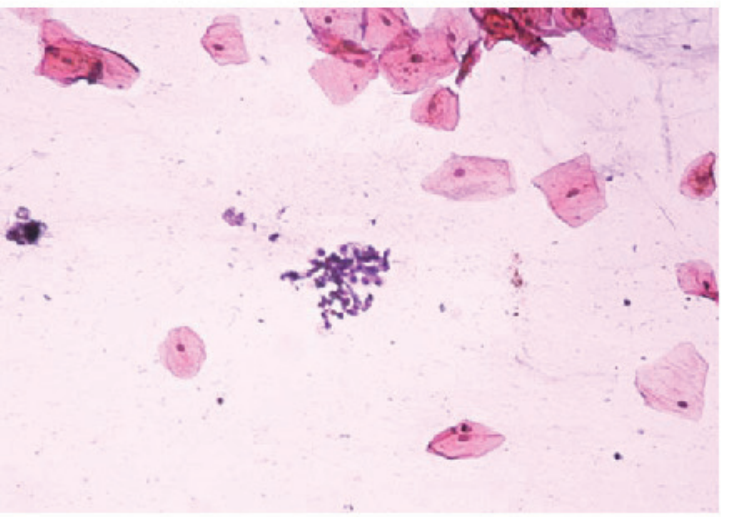

Atypia and inflammatory cells
The association between the duration and type of shamma use is presented in Table 3 . White shamma use induced the incidence of the abnormal cytology by the increase in the use frequency, unlike the results of Suhaily and black shamma.
The majority of the shamma associated cytology $(13 / 14)$ were seen in the tissues from the participants of the age group 18-44 years, while only one abnormal result belonged to the participants of the age group 45-64 years (Figure 3). 
Table 2. Shamma types and their Papanicolaou staining results $(\mathrm{N}=61)$

\begin{tabular}{|c|c|c|c|c|c|}
\hline \multirow[t]{2}{*}{ SN } & \multirow[t]{2}{*}{$\begin{array}{l}\text { Shamma } \\
\text { type }\end{array}$} & \multirow[t]{2}{*}{ II } & \multicolumn{2}{|c|}{$\begin{array}{c}\text { Shamma associated } \\
\text { abnormal results }\end{array}$} & \multirow[t]{2}{*}{ p } \\
\hline & & & n & $\%$ & \\
\hline 1 & Suhaily & 36 & 9 & 25 & 0.0014 \\
\hline 2 & Black & 9 & 2 & 22.2 & 0.08 \\
\hline 3 & White & 6 & 2 & 33.3 & 0.43 \\
\hline 4 & Grey & 4 & 0 & 0 & - \\
\hline 5 & Yellow & 3 & 0 & 0 & - \\
\hline 6 & Red & 1 & 1 & 50 & 1.00 \\
\hline 7 & Brown & 1 & 0 & 0 & - \\
\hline 8 & Afzal & 1 & 0 & 0 & - \\
\hline Total & & 61 & 14 & 22.95 & $\leq 0.0000$ \\
\hline
\end{tabular}

Table 3. Effect of duration and frequency of shamma use on mouth cytology

$\begin{array}{lccccc}\text { Duration } & \text { Type of shamma } & \text { Vormal } & \text { Abnormal } & \text { Total } \\ \text { (years) } & \text { Suhaily } & 1-5 & 14 & 6 & 20 \\ & & 6-10 & 13 & 3 & 16 \\ & \text { Black } & 1-5 & 4 & 2 & 6 \\ & & 6-10 & 3 & 0 & 3 \\ & \text { White } & 1-5 & 2 & 1 & 3 \\ & 6-10 & 2 & 1 & 3 \\ \text { Frequency } & \text { Suhaily } & 1-5 & 16 & 7 & 23 \\ \text { (times/day) } & & 6-10 & 8 & 2 & 10 \\ & & 11-15 & 3 & 0 & 3 \\ & \text { Black } & 1-5 & 6 & 2 & 8 \\ & & 6-10 & 1 & 0 & 1 \\ & & 11-15 & 0 & 0 & 0 \\ & \text { White } & 1-5 & 2 & 0 & 2 \\ & & 6-10 & 0 & 1 & 1 \\ & & 11-15 & 2 & 1 & 3\end{array}$

Figure 3. The Pap stain cytology results of the participants within the different age groups

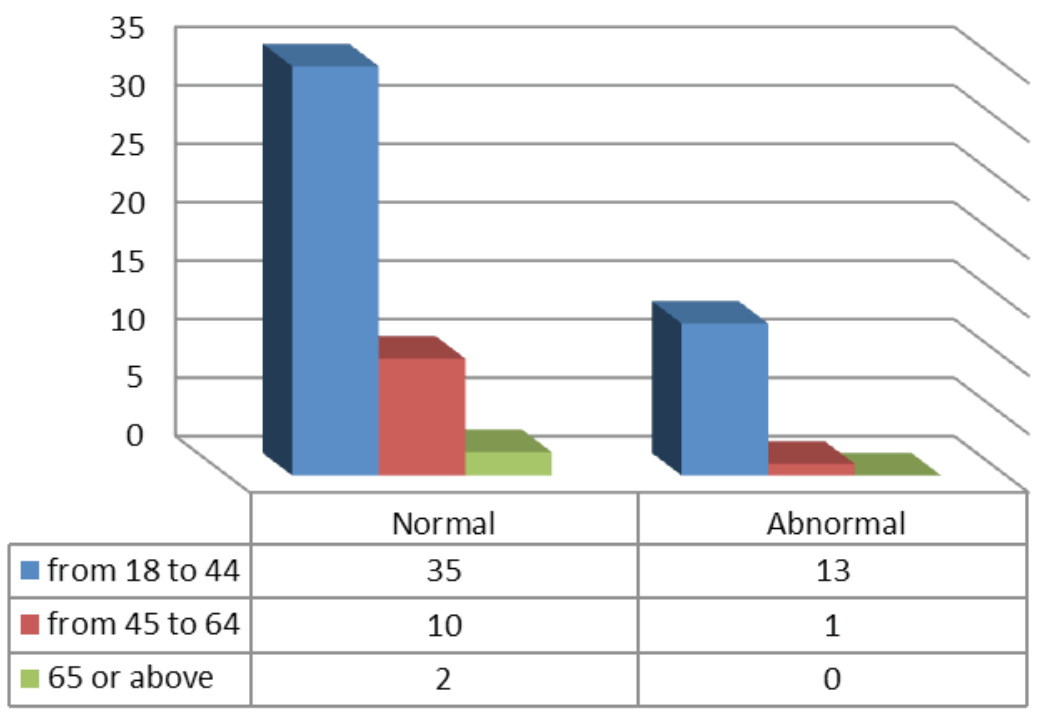

\section{DISCUSSION}

In this study smokeless tobacco (shamma) use was found to be associated with three abnormal cytology results: keratinization, binucleation, and combinations such as atypia and inflammation. The abnormal mouth cytology results were driven by the type of smokeless tobacco rather than the duration or frequency of smokeless tobacco use or the age of the dippers.

Previous research found that keratinization was found in all the scrapes of oral mucosa from Sudanese Toombak (Sudanese smokeless tobacco) dippers.
Ahmed et al. ${ }^{15}$ found that $53 \%$ of their study population was characterized by excessive keratinization, a fact also found by other researchers ${ }^{11,15,16}$. Surprisingly, smokeless tobacco-induced keratinization has a benefit: it prevents aphthous stomatitis of the oral mucosa. Aphthous stomatitis is a painful recurrent ulcer of unknown cause ${ }^{17}$. Keratinization is one of the early indicators and poor prognosis of oral squamous cell carcinoma ${ }^{18,19}$, and may be involved in the aetiology of oral cancers.

In accordance with our findings, Indian studies 
showed the presence of binucleated buccal mucosa cells in smokeless tobacco users ${ }^{20,21}$. Chen ${ }^{22}$ in 1989 treated 30 rats with smokeless tobacco for one year and observed that the smokeless tobacco-induced formation of numerous binucleate spinous cells. Many studies correlated dysplasia and malignancy lesions in the oral mucosa with the use of smokeless tobacco ${ }^{11,16,23-25}$. An in vitro study mentioned that smokeless tobacco might induce inflammatory reactions through recruitment of leucocytes in the smokeless tobacco use sites ${ }^{25}$. Studies from Uzbekistan and India found that smokeless tobacco use is associated with inflammation, alveolar bone damage, dysplasia, and squamous cell carcinoma. Smokeless tobacco was also correlated with an increased blood level of IL- $12^{26,27}$. However, oral inflammation is an important consequence of oral squamous cell carcinoma progression ${ }^{28}$.

Regarding the effect of the duration and frequency of smokeless tobacco use, many studies found that the duration and frequency of smokeless tobacco use were associated with cytological changes and malignant transformations ${ }^{1,5,29}$. Similar to our findings, Daniels et al. ${ }^{30}$ found that the duration and frequency of smokeless tobacco use are not associated with epithelial changes while they are associated with smokeless tobacco type.

The similarities and differences between the findings of this study and previous studies may be due to the ethnic origin and the different types of smokeless tobacco. Differences were reported when the findings of this study were compared to African studies, whereas similarities were seen when the findings of this study were compared to studies from Asia and the Indian peninsula.

\section{Limitations}

Our study has a number of limitations, including the small number of samples overall and within subgroups assessed. Moreover, by design this study cannot determine the causes of the abnormal results, while this study did not quantify the abnormalities such as the number of binucleated cells so as to find an association between them and the type of smokeless tobacco, duration and frequency of use, and age of users. To overcome the limitations of this study, more comprehensive research with a large number of samples are planned for the near future.

\section{CONCLUSIONS}

Oral mucosa histological changes associated with smokeless tobacco (shamma) use in Saudi Arabia were found to be inflammation, keratinization, binucleation, and atypia.

\section{REFERENCES}

1. Garg KN, Raj V, Chandra S. Trends in frequency and duration of tobacco habit in relation to potentially malignant lesion: A 3 years retrospective study. J Oral Maxillofac Pathol. 2013;17(2):201-206. doi:10.4103/0973-029X.119760

2. American Cancer Society. Health Risks of Smokeless Tobacco. http://www.cancer.org/cancer/cancercauses/ tobaccocancer/smokeless-tobacco. Accessed November 25, 2016.

3. Pindborg JJ, Reibel J, Roed-Petersen B, Mehta FS. Tobacco-Induced Changes in Oral Leukoplakic Epithelium. Cancer. 1980;45:2330-2336. doi:10.1002/1097-0142(19800501)45:9<2330::aidcncr2820450916>3.0.co;2-r

4. Jungell P, Malmström M. Snuff-induced lesions in Finnish recruits. Scand J Dent Res. 1985;93(5):442-447. doi:10.1111/j.1600-0722.1985.tb01337.x

5. Holmstrup P, Pindborg JJ. Oral Mucosal Lesions in Smokeless Tobacco Users. CA-A Cancer Journal for Clinicians. 1988;38(4):230-235. doi:10.3322/canjclin.38.4.230

6. Walsh PM, Epstein JB. The Oral Effects of Smokeless Tobacco. J Can Dent Assoc. 2000;66:22-25.

7. Al-Abbadi MA. Basic of Cytology. Avicenna J Med. 2011;1(1):18-28. doi:10.4103/2231-0770.83719

8. Mohanta A, Mohanty PK, Parida G. Cytomorphometric analysis of keratinized round cells in human oral carcinoma. J Cytol. 2015;32(2):107-112. doi:10.4103/0970-9371.160561

9. Alsanosy RM. Smokeless Tobacco (Shammah) in Saudi Arabia: A Review of its Pattern of Use, Prevalence, and Potential Role in Oral Cancer. Asian Pacific Journal of Cancer Prevention. 2014;15:6477-6483. doi:10.7314/APJCP.2014.15.16.6477

10. Siddiqi K, Shah S, Abbas SM, et al. Global burden of disease due to smokeless tobacco consumption in adults: Analysis of data from 113 countries. BMC Med. 2015;13:194. doi:10.1186/s12916-015-0424-2

11. Zhang X, Schmitz W, Gelderblom HR, Reichart PA. Shammah-induced oral leukoplakia-like lesions. Oral Oncol. 2001;37(7):609-612. doi:10.1016/s1368-8375(00)00123-8

12. Sánchez-Siles M, Camacho-Alonso F, Ros-Llor I, López-Jornet P. Cytogenetic biomonitoring in oral leukoplakia patients with mild dysplasia. Int J Dermatol. 2014;53(12):1454-1459. doi:10.1111/ijd.12223

13. Mehrotra R, Gupta A, Singh M, Ibrahim R. Application of cytology and molecular biology in diagnosing premalignant or malignant oral lesions. Mol Cancer. 
2006;5:11. doi:10.1186/1476-4598-5-11

14. Merck Milipore. Cytodiagnosis Staining Methods. http:// www.lolab.de/download/info_hersteller/w287127_ cytodiagnosis_e_130121.pdf. Published 2013. Accessed November 26, 2016.

15. Ahamed HG, Hamid HHM, Mahmoud AH, Elhussein GE. Utility of keratinization and Mean NOR as Neoplastic Proliferative predictors of oral mucosal alterations related to carcinogenic exposure. European Academic Research. 2016;III(11):11797-11814.

16. Daniels TE, Chou L, Greenspan JS, et al. Reduction of Langerhans cells in smokeless tobacco-associated oral mucosal lesions. J Oral Pathol Med. 1992;21(3):100-104. doi:10.1111/j.1600-0714.1992.tb00990.x

17. Grady D, Ernster VL, Stillman L, Greenspan J. Smokeless tobacco use prevents aphthous stomatitis. Oral Surg Oral Med Oral Pathol. 1992;74(4):463-465. doi:10.1016/0030-4220(92)90296-3

18. Mohanta A, Mohanty PK, Parida G. Keratinized strap cells: a rare cytological atypia resembles Anitschkow cells, in human oral neoplasm. Int J Clin Oncol. 2016;21(1):5967. doi:10.1007/s10147-015-0865-9

19. Cooper T, Biron VL, Adam B, Klimowicz AC, Puttagunta L, Seikaly H. Association of keratinization with 5-year disease-specific survival in oropharyngeal squamous cell carcinoma. JAMA Otolaryngol Head Neck Surg. 2015;141(3):250-256. doi:10.1001/jamaoto.2014.3335

20. Sharma V, Zaveri KK, Patel MM, Singel TC. Effect of Duration of Exposure of Smokeless Tobacco on the Buccal Mucosal Cytology in the Male Population as Compared to Non-Exposed in the Saurashtra Region of Gujarat State. Biomirror. 2015;6(8):80-81

21. Kausar A, Giri S, Mazumdar M, Giri A, Roy P, Dhar P. Micronucleus and other nuclear abnormalities among betel quid chewers with or without sadagura, a unique smokeless tobacco preparation, in a population from North-East India. Mutation Research. 2009;677:72-75. doi:10.1016/j.mrgentox.2009.05.007

22. Chen SY. Effects of smokeless tobacco on the buccal mucosa of HMT rats. J Oral Pathol Med. 1989;18(2):108112. doi:10.1111/j.1600-0714.1989.tb00745.x

23. Gupta J, Gupta KK, Kabiraj A, Samadi FM. Smokeless Tobacco and Oral Cancer: A Review. Indian Journal of Oral Sciences. 2012;3(2):74-78. doi:10.4103/0976-6944.106458

24. Shirani S, Kargahi N, Razavi SM, Homayoni S. Epithelial Dysplasia in Oral Cavity. Iran J Med Sci. 2014;39(5):406417.

25. Furie MB, Raffanello JA, Gergel EI, Lisinski TJ, Horb LD. Extracts of smokeless tobacco induce pro-inflammatory changes in cultured human vascular endothelial cells. Immunopharmacology. 2000;47(1):13-23. doi:10.1016/s0162-3109(99)00181-2

26. Gulyamov S, Gaybullaev EA, Sadykov RR. Smokeless Tobacco-Associated Lesions of the Oral Cavity. European
Science Review. 2016;7(8):63-65.

27. Dwivedi S, Goel A, Khattri S, Sharma P, Pant K. Aggravation of Inflammation by Smokeless Tobacco in Comparison of Smoked Tobacco. Ind J Clin Biochem. 2015;30(1):117-119. doi:10.1007/s12291-014-0467-8

28. Sarode GS, Sarode SC, Patil A, et al. Inflammation and Oral Cancer: An Update Review on Targeted Therapies. J Contemp Dent Pract. 2015;16(7):595-602. doi:10.5005/jp-journals-10024-1727

29. Aishwarya KM, Reddy MP, Kulkarni S, Doshi D, Reddy BS, Satyanarayana D. Effect of Frequency and Duration of Tobacco Use on Oral Mucosal Lesions - A Cross-Sectional Study among Tobacco Users in Hyderabad, India. Asian Pacific Journal of Cancer Prevention. 2017;18:2233-2238. doi:10.22034/APJCP.2017.18.8.2233

30. Daniels TE, Hansen LS, Greenspan JS, et al. Histopathology of smokeless tobacco lesions in professional baseball players: Associations with different types of tobacco. Oral Surgery, Oral Medicine, Oral Pathology. 1992;73(6):720725. doi:10.1016/0030-4220(92)90018-1
CONFLICTS OF INTEREST

The authors have completed and submitted the ICMJE Form for Disclosure of Potential Conflicts of Interest and none was reported.

\section{FUNDING}

This study was funded by the Deanship of scientific research at King Khalid University (grant number R.G.P.1/7/40).

PROVENANCE AND PEER REVIEW

Not commissioned; externally peer reviewed. 